Jurnal Ilmu Sosial Volume 19 | Issue 2 | December 2020 | Page 117-136

Available online at JIS website: https://jis.undip.ac.id

Research Article

\title{
Celebrities in the Recruitment of Candidates for Legislative Members of the Indonesian Parliament in the Legislative Elections
}

\author{
Received: $29^{\text {th }}$ May 2020; Revised: $15^{\text {th }}$ July 2020; \\ Accepted: $20^{\text {th }}$ July 2020; Available online: $25^{\text {th }}$ July 2020
}

\begin{abstract}
M. Dwi Sugiarto, Yuwanto
Master of Political Science, Faculty of Social and Political Sciences, Universitas Diponegoro, Jl. Imam Bardjo, SH, No. 1, Semarang, 1269, Indonesia
\end{abstract}

\begin{abstract}
The 2019 Legislative Election featured many celebrities involved in the contestation, where a total of 11 of the 16 political parties had legislative candidates from the celebrity circles. Democratic National Party (NasDem) became the party that nominated most celebrities as legislative candidates. Armed with the popularity that has made celebrities attract political parties to nominate them to increase the vote acquisition and even the number of seats. The process of recruiting legislative candidates from celebrities by the NasDem Party is the focus of this research on how the approach and process are carried out. The study uses qualitative analysis with a descriptive approach to describe the process that occurs through interviews and review of documents and news as a source of data. The results obtained indicate that the NasDem Party's legislative candidate was recruited using an approach that involved the NasDem Party elite and fellow celebrities as intermediaries. Factors driving celebrities to become the NasDem Party's legislative candidates are moral support (debriefing, fostering, and active interaction with party elites) and material (Campaign Props, campaign costs, financial reimbursement), Indonesian Restoration slogans, and anti-dowry politics, as well as egalitarian politics attitudes. Celebrity-related research in politics has focused a lot on the role of transformation from entertainment to politics. In contrast, this research has focused on recruiting celebrities as legislative candidates by the NasDem Party.
\end{abstract}

Keywords: Political Recruitment; Celebrity Candidates; Legislative Elections; Political Parties; NasDem Party.

How to Cite: Sugiarto, M. D., Yuwanto. (2020). Celebrities in the Recruitment of Candidates for Legislative Members of the Indonesian Parliament in the Legislative Elections. Jurnal Ilmu Sosial, 19 (2): 117-136 (doi: 10.14710/jis.19.2.2020.117-136), [Online]

Permalink/DOI: https://doi.org/10.14710/jis.19.2.2020.117-136

Corresponding Author: mdsugiarto1908@gmail.com (M. Dwi Sugiarto) 


\section{Jurnal Ilmu Sosial Volume 19 | Issue 2| December 2020 | Page 117-136}

\section{INTRODUCTION}

The presence of celebrities in political contestation is not a new trend. In various countries, celebrities' appearance on the political stage has even reached political office as president such as the 40th President of the United States Ronald Reagan (actor), George Weah the 25th President of Liberia (football athlete), and most recently is the 6th President of Ukraine Volodymyr Zelenskiy (actor/comedian) (Gustidha: 2019). Celebrity is a profession that comes from the sports and entertainment industry; they are easily found on the media; and their private lives will attract public attention rather than their professional lives (Alfito: 2008). According to Daniel J. Boorstin, as quoted by Eep Saefulloh Fatah, celebrities are known for their fame. Heroes recognized for their achievements, while celebrities from their image or trademark. Heroes form themselves, while the media form celebrities. Heroes are big people, while celebrities are big names (Dewi: 2011).

In Indonesia, celebrities' involvement in politics is limited to the Regional Election (Pilkada) level and the legislature as a member of the Indonesian Parliament (DPR RI). After the New Order ended, celebrities involved in politics continued to experience an increase in the role they carried out, namely as a magnet to gather the masses when an open campaign was carried out. The role that initially as a vote getter in the context as a celebrity endorser, becomes a vote getter in the context of a celebrity politician (Ikhsan: 2015).

Table 1. Celebrity Legislature Candidates in Every Legislative Election

\begin{tabular}{cccc}
\hline \multicolumn{4}{c}{ Celebrity Legislature Candidates } \\
\hline 2004 & 2009 & 2014 & 2019 \\
38 & 61 & 77 & 92 \\
\hline
\end{tabular}

\section{Source: Processed from various sources.}

Based on Table 1, the number of participating legislative candidates in each legislative election continues to increase. The increase in celebrity legislative candidates' participation occurred since the legislative elections were held using the open proportional system, namely in the 2004 Legislative Elections to the 2019 Legislative Elections. The most substantial increase in margin occurred in the 2009 Legislative Elections, with 23 celebrities registered as legislative candidates. The increase occurred in the 2014 legislative elections with 16 legislative candidates. In the 2019 legislative elections, there was an increase with 15 celebrity legislative candidates. The increasing participation of celebrity legislative candidates is influenced by several factors, 


\section{Jurnal Ilmu Sosial Volume 19 | Issue 2| December 2020 | Page 117-136}

including the election system used. The electoral system relates to all aspects related to the holding of elections which influences the implementation of elections, including for political parties related to political strategy.

Table 2. Legislative Election System

\begin{tabular}{cc}
\hline Election Year & Election System \\
\hline 2004 & Open Proportional System (serial number) \\
2009 & Open Proportional System (popular vote) \\
2014 & Open Proportional System (popular vote) \\
2019 & Open Proportional System (popular vote) \\
\hline
\end{tabular}

Source: Processed from various sources.

Based on Table 2, the electoral system used remains the same in the last four legislative election periods. An open proportional system presents a form of legislative election contestation that allows voters to vote for the candidates they support directly. This model makes the names of legislative candidates directly listed in the ballot so that voters directly choose the names of legislative candidates that are available. The term proportional system only shows the distribution of quota seats contested in an electoral district, and the winner's determination divided based on the number of votes. Meanwhile, the term open in proportion emphasizes the voters who can participate in determining the order of the party candidates be elected. In addition, it needs to be seen in the election process in the participation of celebrity legislative candidates is the final result of their election.

The increase in the number of celebrity legislative candidates' participation was not directly proportional to the number of celebrities who succeeded in winning the legislative seat. In the 2009 Legislative Elections, there were 18 names of celebrities elected as Members of the Indonesian Parliament for the 2009-2014 Period (Seconds: 2009). Then, in the 2014 Legislative Elections, reduced to 16 names of celebrities who succeeded in winning the votes of the constituents and made them as Members of the Republic of Indonesia Parliament for the 2014-2019 Period (Scholastica: 2018). In the 2019 Legislative Elections, however, only 13 celebrity names won the people's votes and were entitled to become Members of the Republic of Indonesia Parliament for the 2019-2024 Period. However, there is one celebrity legislative candidate, Mulan Jameela (Gerindra), who was also inaugurated after the Gerindra Party had previously made the process of replacing seats in the Electoral District XI in West Java. Thus, 14 celebrities were Members of the Indonesian Parliament for the 2019-2024 Period (Dhawam: 2019). The number of celebrity 


\section{Jurnal Ilmu Sosial Volume 19 | Issue 2| December 2020 | Page 117-136}

electability in the legislative election contestation is declining. However, at the same time, the participation rate of celebrity legislative candidates is increasing. This figure indicates the difference in viewpoints between voters and political parties supporting celebrity legislative candidates and celebrity legislative candidates themselves. For some people, celebrity is not seen as the best choice to become a people's representative. On the one hand, political parties see popularity as support in winning popular votes. On the other hand, celebrities see that their popularity has the potential to influence people's choices during elections.

Table 3. Distribution of Celebrity Legislative Candidates in 2019 Legislative Elections

\begin{tabular}{clc}
\hline \multicolumn{3}{c}{ Celebrity Legislative Candidates in Every Political Party } \\
\hline $\begin{array}{c}\text { Serial } \\
\text { Number }\end{array}$ & \multicolumn{1}{c}{ Party Name } & $\begin{array}{c}\text { Celebrity Legislative } \\
\text { Candidates }\end{array}$ \\
\hline 1 & National Awakening Party (PKB) & 6 \\
2 & Great Indonesia Movement Party (Gerindra) & 6 \\
3 & Indonesian Democratic Party of Struggle & 16 \\
& (PDIP) & 2 \\
4 & Party of Functional Groups (Golkar) & 37 \\
5 & Democratic National Party (Nasdem) & 0 \\
6 & Garuda Party & 4 \\
7 & Berkarya Party & 0 \\
8 & Prosperous Justice Party (PKS) & 7 \\
9 & Indonesian Unity Party (Perindo) & 0 \\
10 & United Development Party (PPP) & 1 \\
11 & Indonesian Solidarity Party (PSI) & 9 \\
12 & National Mandate Party (PAN) & 1 \\
13 & People's Conscience Party (Hanura) & 3 \\
14 & Democratic party (Demokrat) & 0 \\
19 & Crescent Star Party (PBB) & 0 \\
20 & Indonesian Justice and Unity Party (PKPI) & \\
\hline
\end{tabular}

Source: Processed from various sources.

Looking at the distribution of celebrity legislative candidates, as shown in Table 3, it shows that most political parties participating in the 2019 Legislative Election have celebrity legislative candidates. Based on the 2019 Legislative Election Permanent Candidates list, NasDem Party has the most celebrity legislative candidates. Of the 16 political parties, only the Garuda Party, PPP, PKS, PBB, and PKPI that have no celebrity legislative candidates. The enthusiasm and trust of political parties to nominate celebrities as legislative candidates have a sizable per- 


\section{Jurnal Ilmu Sosial Volume 19 | Issue 2| December 2020 | Page 117-136}

centage of $68.75 \%$. The attitude of many political parties nominating celebrity legislative candidates shows that first, political parties are increasingly open to being willing to nominate celebrities to face political contestation. Second, celebrities are increasingly actively involved in the world of politics with status as political actors. Negative views then emerge from the participation of celebrities in politics. Political parties are considered for prioritizing pragmatism more than optimizing regeneration because the status and role of political parties are central in the democratic system (people's sovereignty). Political parties are the pillars of democracy (often regarded as one of the political infrastructures) because they play an essential role as liaisons between state governments and citizens (Jimly, 2008: 710).

The recruitment and regeneration processes so far tend to apply "traditional" patterns and styles. Catch-all parties characterize the developed party, does not yet have a clear and specific social basis, and still depends on individual figures. Political parties also face challenges in the regeneration process. Most political parties do not yet have a transparent cadre system, so the source of political recruitment tends to be oligarchic. The problem in political recruitment and regeneration is the dominance of party leaders in the selection process and proposing candidates for legislative members in Indonesia. The description of jop-hopper politicians, cadres of artists or comedians, rich people, and entrepreneurs who are often doubtful of their political abilities is one of the phenomena of the many problems in the process of political recruitment and nomination carried out by political parties (Syamsuddin, 2016: 4). The presence of jop-hopper politicians, celebrity cadres, rich people, and businessmen makes public doubts that political parties put forward the pragmatic side in carrying out political regeneration. Thus, the general views political parties as failing in carrying out education and political regeneration in carrying out the functions of political recruitment.

The importance of political recruitment for political parties makes the functions of other political parties less meaningful if political parties fail in the function of political recruitment (Syamsuddin, 2016: 61). The process of nominating candidates carried out by political parties needs to be considered to ensure the quality of the candidates carried. Recruitment by political parties will produce quality political products (political actors) if done well. Strict supervision of the community, combined with party foresight in selecting candidates, will bring significant changes in the body of the party itself (Muhtar, 2016: 31).

Political recruitment (political recruitment) is a function of selecting people for political activities and government positions through appearances in communication media, becoming members of organizations, running for certain positions, education, and so on (Mas'oed, 1999: 


\section{Jurnal Ilmu Sosial Volume 19 | Issue 2| December 2020 | Page 117-136}

29). Recruiting, educating, and occupying seats in parliament is an essential function of democracy for political parties (Thomas, 2012: 33). There are two standard models of political recruitment, namely, open recruitment and covert recruitment. Open recruitment is carried out for all citizens who meet the conditions specified and have the talent, without exception, to have the same opportunity to occupy political positions and government positions. Meanwhile, closed recruitment only provides opportunities for certain people, such as close friends, business people, or individuals who have the same religious, regional, ethnic, and even family members of the ruling elite (Muhadam, 2015: 19). The closeness factor becomes quick access to reach a political position, as illustrated in the nominating women in the elections that were heavily influenced by kinship or political dynasties. This practice can be called a form of exclusivity in politics and is contrary to the nature of democracy, which is inclusive (Fitriyah, 2018). The selection and recruitment of candidates can be described as a political "secret garden," which is an unclear process. This process is often hidden from outside view, which is primarily governed by internal party rules, informal practices, and related to power relations (Kenny M. et al.: 2015). The recruitment process, especially associated with the nomination for political office, shows a closed tendency. Political actors who are close to party elites can easily get nomination recommendations to be nominated. Effective recruitment depends very much on how the recruitment experience is carried out, and the response received from the community for the recruitment effort (Jessica: 2015).

The presence of celebrities as politicians has an impact on changes in the way traditional political actors present themselves. The tendency that ensues shows the personalization of leadership from political actors to be like celebrities; this can also be said as a celebrity political effort. Political actors adopt platforms and communication models that originate directly from popular culture and entertainment (Maja: 2016). Characters attached to celebrities are identified as largely unstable categories, and can even change in a relatively short time. The role of the media in building an image with a celebrity identity is influential (Olivier: 2013). A high celebrity image is a potent tool to enhance a brand's image. The use of celebrities in advertising can help attract extraordinary attention to a brand. That is why celebrities' presence to introduce a brand is always followed by the issuance of costs by the brand owner (Kumar: 2017).

The bargaining value as a celebrity in the form of popularity becomes a valuable capital that all politicians not share, and this is welcomed by political parties to win political contestation. Political parties, as an organization of political activists, try to control the power of government and gain popular support based on competition with a group or other groups with different 


\section{Jurnal Ilmu Sosial Volume 19 | Issue 2| December 2020 | Page 117-136}

views (Miriam, 2008: 404). So, it is not surprising that political parties generally appear oriented to power as catch-all party type (Luky, et al. 2017: 108). This article presents the NasDem Party as a subject in recruiting celebrities as legislative candidates and the factors that make celebrities choose the NasDem Party as a vehicle to move forward in the 2019 Legislative Election. Research on celebrities in politics in previous studies (state of the art) looks more at celebrity aspects are generally related to popularity as a political tool in Dyah's research (2017), as well as celebrity involvement that occurred after the New Order which was influenced by the electoral system in Ikhsan's research (2015). The two studies do not show the recruitment process by political parties towards celebrity legislative candidates. Research on political recruitment of legislative candidates mostly speaks to the process carried out on legislative candidates in general such as the Golkar Party in the Teguh research (2013), PKS in Fernanda research (2012), and on several political parties in the region in recruiting legislative candidates in research Ahmad et al. (2015).

The novelty of this research emphasizes the specificity of a political party in carrying out the process of political recruitment of a social identity that is attached to the characteristics of celebrities to be candidates for legislative members. The NasDem Party, as the political party participating in the 2019 Legislative Election with the highest number of celebrity legislative candidates, invited questions about the political policy it took and the process of joining the celebrity. Celebrity recruitment tends to be done quickly, where celebrities who change parties or who have just entered politics take place in a relatively short time. The results in this study were to determine the political process carried out by the NasDem Party in offering bids to their celebrity legislative candidates as well as in terms of celebrity legislative candidates in seeing the NasDem Party's political image and reasons for choosing it as a vehicle.

\section{RESEARCH METHODS}

This article has a focus of study on the recruitment process of celebrity legislative candidates conducted by the NasDem Party in the 2019 Legislative Election. The author conducted this research using qualitative analysis methods (Creswell, 2016: 4-5) through a descriptive approach (Burhan, 2012: 66). The study results took the form of a narrative description of the focus of the research, namely the recruitment process of celebrity legislative candidates conducted by the NasDem Party. The data used in the form of primary data obtained through interviews, while secondary data collected through supporting literature and documentation. 


\section{Jurnal Ilmu Sosial Volume 19 | Issue 2| December 2020 | Page 117-136}

The process of collecting data by conducting in-depth interviews is done with several informants and literature through a literature review (Soerjono, 2011: 66). The informants' selection was carried out randomly against several celebrity legislative candidates and the board members of the NasDem Party Central Board. Some informants selected from the celebrity legislative candidates are Afdhal, Adly Fairuz, Bertrand Antolin, Iman Dwi Saputro, Krisna Mukti, and Livy Andriyani. Meanwhile, the informant from the board of the NasDem Party Central Leadership Board was the Chair of the Media and Communication Division, Willy Aditya.

Data processing in this study uses the process of data reduction (summarizing and selecting data), data display, and verification (drawing conclusions) (Soerjono, 2011: 66). Data that has been collected both through interviews and literature, as well as existing documentation, is then carried out the process of data reduction, which is summarizing and selecting and sorting data. After the selected data can be used, the data is presented (display data) to be arranged so that the conclusion can be made, which becomes a finding of the research process.

To maintain data quality, the authors use the source triangulation and theory triangulation method (Moleong, 2002: 135). Source triangulation in this study was conducted by collecting data from various sources using the interview method. Meanwhile, the triangulation of theories is done by comparing them using theories related to research.

\section{RESULTS AND DISCUSSION}

\section{a. Recruitment of Celebrity Legislative Candidates of the NasDem Party}

The 2019 election had several differences compared to the 2014 election, including the requirement for Parliamentary Threshold (PT), which increased from 3.5\% to $4.0 \%$. Second, the implementation was synchronized between the 2019 Legislative Election and the 2019 Presidential Election on the same day. In contrast, in the 2014 Election, the legislative election was held first (April) and the presidential election (July). Third, the number of political parties participating in the legislative election increased to 16 national parties and 4 Aceh local parties. In contrast, in the 2014 election, only 12 national parties and 3 Aceh local parties were followed. Fourth, the model of converting votes into seats in the 2014 Legislative Election which uses 'quota' (Bilangan Pembagi Pemilih) for the price of a seat in an electoral area, while the 2019 Legislative Election uses the sainte lague model, which divides the party's overall vote by odd numbers $(1,3,5,7,9$, etc.) of the total party votes (the votes of legislative candidates and votes for the party) to win seats in the electoral district. 


\section{Jurnal Ilmu Sosial Volume 19 | Issue 2| December 2020 | Page 117-136}

The NasDem Party faces the 2019 Legislative Election with a big target: to penetrate the top three national votes and 100 seats in the Indonesian Parliament (Putra: 2019). With the stated target, compared with the results obtained in the 2014 Legislative Elections (i.e., 8th with 36 Parliament seats), making the right strategy needed to win a major vote for the NasDem Party. The strategy used by the NasDem Party includes carrying out public figures as legislative candidates such as incumbent members of the Indonesian Parliament for the 2014-2019 Period (Nur Azizah: 2019). According to a survey conducted by the Center for Strategic and International Studies (CSIS), the NasDem Party has become a favorite destination for several incumbents' migration. A total of 20 incumbents who moved political parties from 31 people made the NasDem Party their goal. The movement is influenced by good communication, and bidding factors, namely offers in the form of permanent electoral districts, permanent or even ascending serial numbers, or in terms of publication considered more promising (Andreas: 2019). NasDem Party publications are seen as more active than other political parties where the party led by Surya Paloh often appears and is reported by Metro TV.

The recruitment process of the NasDem Party's legislative candidates is carried out using four patterns, namely open recruitment, talent scouting, grooming, and "figure recommendations." Open recruitment, in addition to being intended for the general public, it is also intended to be a process that is conveyed to the public through various existing media. NasDem Talent scouting is done by picking up and applying for legislative candidates who are deemed capable of carrying out their duties and under party criteria. The proactive process by applying for legislative candidates to be nominated by the NasDem Party certainly has provisions from the party. It becomes part of the strategy to meet the composition of the needs of candidates for the legislature that will be carried. This recruitment pattern has been carried out by the NasDem Party since facing the 2014 Legislative Election. Grooming is intended to maintain communication with someone who is considered potential. As a political party that actively builds networks to the public, the NasDem Party has figures that have been linked. Communication has been carried out, and the NasDem Party can be well maintained so that recruitment into party members can be done. By asking for "figures' recommendations" from several figures to give names deemed appropriate and suitable for the NasDem Party's legislative candidates. Recommendations from figures that are considered to have influence and can provide recommendations for legislative candidates become a strategy by involving external parties and as a way for the NasDem Party to build political relations with influential figures. An illustration of this figure's recommendations can be seen from the relationship of several NasDem Party legislative candidates who have connections with figures in this country, for example, Davin Kirana (son of Rusdi Kirana who is the founder 


\section{Jurnal Ilmu Sosial Volume 19 | Issue 2| December 2020 | Page 117-136}

of Lion Air), a relative of a political figure such as Arkanata Akram (Son of the Governor of North Kalimantan), Hillary Brigitta Lasut (Putri Regent of Talaud Islands), Percha Leanpuri (Putri of South Sumatra's Governor). In addition, many relatives of pesantren figures also advanced to the legislative candidate from the NasDem Party. This fact can be a supporter of the NasDem Party's legislative candidate recruitment process through a recommendation from a figure.

In addition, political education for cadres who will be nominated in political contestation is also essential. This aspect is support for the qualities needed by political actors as part of political regeneration. The NasDem Party has a political education institution called the State Defence Academy, which is the first political education institution/institution formed by an Indonesian political party in the current era. The academy is designed to facilitate the political education of national cadres to be able to become agents of change who can read social dynamics in the realm of democracy, and of course, the power to behave and act wisely, effectively, and responsibly. The political education model at the State Defence Academy is organized in the form of lecture classes consisting of cadre schools, legislative schools, and executive schools. The education provided is beneficial, especially for new politicians such as celebrities who still lack political experience. Celebrities also go through the same educational process as other legislative candidates at the National Defense Academy, including incumbent celebrity legislative candidates for members of the Indonesian Parliament. In addition to the incumbent, the NasDem Party's legislative candidate is filled with a party-switching celebrity and new politician celebrity.

Celebrity legislative candidates from incumbent Members of the Republic of Indonesia Parliament for the 2014-2019 Period are Lucky Hakim (from PAN), Krisna Mukti (from PKB), Okky Asokawati (from PPP) and Venna Melinda (from Democrats). Apart from the four celebrities, most NasDem Party legislative candidates are newcomers or called new politician celebrities, such as Thessalonica Indria RAAK “Thessa Kaunang," Ageng Wahono, M. Farhan, Anisa Bahar, Bertrand Antolin, Jonathan Frizzy, Lucky Perdana, Kristina Iswandari, Sahrul Gunawan, Nafa Indria Urbach, Manohara Odelia, Yuli “KDI," Selfi Nafilah “KDI,” Della Puspita, Afdhal, Ferlyanto, Cut Meyriska, Ratna Sulistyaningsih, Imelda Soraya, Kirana Wulan Image, Diana Literature, Hans Christian, Hans Christian, Hans Christian Hosman, Olla Ramlan, Elma Theana Yuliantina, Sylvia Fuly Rahaesita, Five Rachmawati, Fairuz, Helena Andrian, Livy Andriyani, and Kartika Ayuningtyas. Meanwhile, celebrities who have been members of other political parties and are not currently filling political positions or are referred to as party-switching celebrity are Nurul Qomar who has been in the Democratic Party, Ahmad Adly Fairuz who is the Young 


\section{Jurnal Ilmu Sosial Volume 19 | Issue 2| December 2020 | Page 117-136}

PKS icon (a forum for young children in PKS), and Vicky Veranita Yudhasoka "Vicky Shu" who was in the Democratic Party.

The presence of legislative candidates from celebrities and their popularity is a magnet for efforts to introduce political parties to the public. The NasDem Party places celebrity legislative candidates as an "umbrella," which means that their presence is only an ornament in political contestation (Willy: 2019). The choice of the NasDem Party by nominating celebrity legislative candidates as a magnet in introducing the party to the general public is in line with Kumar's (2017) view that celebrities are indeed used to enhance the brand's image so that it is widely known to the public as a promotional tool followed by costs incurred by trademark owners. The NasDem party, as a brand or identity, requires celebrities to be better known by the public. As a consequence, the NasDem Party made the celebrity a legislative candidate with financial assistance.

Providing fees as intended to use the services of celebrities introducing a brand is done by the NasDem Party, assisting in the form of campaign funds such as Campaign Props. In addition to the Campaign Props, the NasDem Party also provides rights that incumbents should receive as members of the Indonesian Parliament for the 2014-2019 period, which will end their term in October 2019. The commitment of the NasDem Party in providing support for the interests of the campaign is not only limited to the Campaign Props but also costs for operations when the campaign such as mobility during the electoral district. In addition to assistance in the form of Campaign Props and operational costs, there are also celebrity legislative candidates who get team assistance to assist them during campaign activities in the electoral district. Not all NasDem Party celebrity legislative candidates are given the same treatment related to assistance in the form of Campaign Props, team support, residences, and vehicles.

In addition to those related to supporting activities during the campaign, the NasDem Party also provides financial assistance or honorarium for celebrity legislative candidates. There are differing statements from celebrity legislative candidates the author interviewed. One of them stated there was no financial assistance besides the Campaign Props. However, when juxtaposed with the answers of other celebrity legislative candidates from the incumbent and one of the nonincumbent celebrity legislative candidates, there is financial assistance. The term used is a replacement for the right as a member of the Indonesian Parliament, which must be in ITS (InterTime Substitution) for joining the NasDem Party since it was registered in the Provisional Candidate List (PCL). Meanwhile, non-incumbent celebrity legislative candidates who claim to get monthly financial assistance (honorarium) from the NasDem Party consider this as something 


\section{Jurnal Ilmu Sosial Volume 19 | Issue 2| December 2020 | Page 117-136}

natural considering they have to leave their activities as celebrities to earn income while being a legislative candidate.

Candidates for celebrity incumbent celebrities do have a higher bargaining value than non -incumbent celebrity legislative candidates. Economic calculations for celebrities because they moved parties later in ITS until the end of their term of office are certainly quite significant. If the ITS is calculated from May 2018 until the end of the term of office for Members of the Republic of Indonesia Parliament for the 2014-2019 period, which is October 2019, then it will be 18 months or one and a half years. Based on the Circular of the Secretariat General of the Republic of Indonesia No. KU.00/9414/DPR RI/XII/2010 concerning the Basic Salary and Allowances of Members of the Parliament (DPR) is Rp63,621,813 per month. The figure is calculated from the amount of salary and benefits and incentives as members of the Indonesian Parliament without the position of chairman or vice-chairman (Chandra: 2019). By looking at the amount of value that the incumbent can still accept, if it is not in ITS because it moves parties, there is a higher value offered by the NasDem Party. The offer given is not only in economic calculations but also in political calculations. The incumbent's political calculations included giving serial number 1 received by Okky Asokawati, Lucky Hakim, and Vena Melinda. In comparison, Krisna Mukti prefers number 5 as the same number as the party number.

Status as the incumbent and non-incumbent legislative candidates have differences in the treatment given by the NasDem Party. The difference between non-incumbent and incumbent can be seen from the perspective of political experience and the potential for electability in legislative election contestation. Thus, the support provided is different between incumbent and nonincumbent, even fellow non-incumbents who have different levels of popularity and level of electability. They are also treated differently by calculating the replacement value of the rights received by the incumbent because ITS does not apply to non-incumbents who do not have financial calculations. However, non-incumbent celebrity legislative candidates are also given financial assistance related to operational campaign costs and Campaign Props.

Efforts made by the NasDem Party in collaboration with celebrities for the sake of increasing party vote gain are seen in the electoral district and the composition of legislative candidates in each electoral district. The distribution of celebrity candidates for the NasDem Party was only concentrated in the Javanese electoral district, the electoral district with the largest votes and the most seats. The electoral districts in Java are almost half of the total electoral districts that are 39 electoral districts out of a total of 80 electoral districts. In Java, there are 3 electoral districts in Jakarta, 11 electoral districts in West Java, 3 electoral districts in Banten, 10 electoral districts in 


\section{Jurnal Ilmu Sosial Volume 19 | Issue 2| December 2020 | Page 117-136}

Central Java, 1 electoral district in Yogyakarta Special Region, 11 electoral districts in East Java. Out of a total of 80 electoral districts in the 2019 Election, Java became the most electoral district with 306 seats out of 575 seats in total. Through celebrity legislative candidates placed in the electoral districts of Java, other targets must be achieved, namely passing the parliamentary threshold. The seizure of large voices in the electoral districts of Java makes the potential for votes contributed to the national vote's interests in the framework of passing the parliamentary threshold more open. Even though the competition to win seats in the Javanese electoral area is fierce, the importance of getting additional votes can still be done.

Therefore, celebrity legislative candidates in the electoral districts mostly do not have a historical relationship with the electoral districts that are occupied, such as the area of origin, place of birth, or lineage. The NasDem Party places its legislative candidates by taking into account the electoral districts' needs and the potential of legislative candidates in getting votes. The term used is man to man marking, which is guarding an area with several players (popular legislative candidates). For example, in one electoral district, there are several candidates for legislative celebrities or a combination with popular political figures. The use of the results of a survey study conducted by a professional survey institution becomes a consideration in determining legislative candidates with electoral districts that are suitable, especially for celebrities who are mostly placed not in their domicile and original area. There are six survey institutions, namely Indikator, Charta Politica, Poltracking, Pusdeham, Indo-Research, and MRC (Median Research Center), in collaboration with the NasDem Party to conduct research related to political mapping. The survey was conducted in full funding by the NasDem Party. For the NasDem Party, this survey is considered more accurate than the survey conducted by internal party researchers (Willy: 2019).

The combination of celebrity legislative candidates, together with political figures called the existing strengthen, is considered a balanced choice considering celebrities can popularize parties. In contrast, political figures can gain votes from grassroots. Political figures called the current increase from relatives of regional heads, former regional heads, and political party elites. They are the ones who are the winner to win at least one seat in each electoral district. The composition of the NasDem Party's legislative candidates is indeed a combination of celebrities, popular political figures, and local politicians.

\section{b. Celebrities Motivation in Joining the NasDem Party}

The role of celebrities in politics, on the one hand, is proof that celebrities already have the awareness to be involved in a more significant portion of the course of government politics in 


\section{Jurnal Ilmu Sosial Volume 19 | Issue 2| December 2020 | Page 117-136}

this country. On the other hand, there is a negative view of celebrities' participation in political contestation that is considered to have insufficient knowledge in politics as well as adequate experience relating to appropriate political and government positions. It must be understood that celebrities as social groups with their profession and background have different interests and need to be fought for in political policies. These interests or needs need to be thought out and fought for by their own groups/celebrities. In society, democracy shows that celebrities can also be elected and trusted to lead in government positions as regional heads or as members of Parliament. The fact that many celebrities nowadays fill political positions also carries a growing stream of other celebrities' interest to try their luck and take part in politics. The experience through stories and influences from fellow celebrities who have already succeeded in their political careers is an example that attracts other celebrities and motivates them to follow the success of their fellow celebrities.

The number of celebrity legislative candidates who choose to join the NasDem Party through the recruitment process to become a legislative candidate is motivated by the value offered. For several celebrity legislative candidates, they considered the idea brought by the NasDem Party, the Indonesian Restoration Change Movement, as a positive movement worth fighting. Indonesian Restoration contains a goal to form a dignified nation, which runs a policy of solidarity, participatory economics, and culture of personality (Willy: 155, 2012). Aside from the Indonesian Restoration Change Movement, another definite idea offered by the NasDem Party is the anti-dowry political policy, which is believed to be the most substantial reason to join several celebrity legislative candidates. Anti-dowry politics as discourse is a selling point that is not inferior to the Indonesian Restoration, even anti-dowry politics are more straightforward in meaning and easy to understand by both the NasDem Party's legislative candidates themselves and the general public. The NasDem Party has succeeded in portraying itself as a political party far from the dirty practices of political dowry.

Incumbents from celebrities who moved to the NasDem Party admit that anti-dowry politics is a magnet, which is why they choose to join (Krisna: 2019). Likewise, with non-incumbent legislative candidates who move parties into the NasDem Party, legislative candidates also have a positive view of NasDem Party's anti-dowry politics (Adly: 2019). For celebrities who are already familiar with politics, they consider that NasDem Party's political move with anti-dowry political policies is a positive step out of dirty political habits by asking dowry for candidates who want to be nominated through political parties. Meanwhile, celebrities who are new to politics also have a similar view of anti-dowry politics as a reason for the joining of several politi- 


\section{Jurnal Ilmu Sosial Volume 19 | Issue 2| December 2020 | Page 117-136}

cians, including celebrities (Faith: 2019). A political observer from the Populi Center, Usep S Ahyar (2019), called the political campaign jargon without a dowry to impress the public and legislative candidates. The jargon is considered very effective in shaping the NasDem Party's selfimage to be more positive.

Beyond the political slogans offered, for celebrities themselves in practice, the anti-dowry policy is the most acceptable reason for their interest in joining the NasDem Party's legislative candidates (Livy: 2019). Celebrities with selling points for their popularity are politically bartered with the opportunity to try their luck in holding government positions and are still economically enforced as celebrities with financial assistance to win. Celebrities who do not need to pay to get recommendations as candidates for the legislature are already an advantage for celebrities compared with other politicians who need fees to get recommendations. In addition, the NasDem Party assists legislative candidates in the form of campaign supplies. Political bids given by the NasDem Party to celebrity legislative candidates in the form of campaign provisions include support in the form of Campaign Props, winning teams, and financial assistance used as operational costs during the campaign (Afdhal: 2019).

Political parties that provide campaign assistance to legislative candidates are something normal considering the interests brought by legislative candidates are the interests of political parties so that this is not something wrong. The capital needed in the face of political campaigns, financial assistance, and social capital, which is quite high, cannot be ruled out for the political process and needed by all candidates.

Motivation on the aspect of political support offered to make celebrities willing to become candidates for the NasDem Party's legislature is bypassed by finding agreements between parties and celebrities. The meeting held between the NasDem Party and celebrities was bridged by several celebrities who had already joined the NasDem Party. The process carried out to make several celebrities willing to join the legislative candidate occurs through two patterns, namely involving the party elite to approach and involving fellow celebrities to find other celebrities to be willing to be legislative candidates by the NasDem Party.

Another factor of the celebrity legislative candidate's interest in the NasDem Party is the party's comfort and conduciveness. Familiarity and the impression of an egalitarian attitude (feeling equal) in the interaction of personal relationships is another reason for celebrities who choose to join the NasDem Party. Several celebrity legislative candidates were impressed by the closeness they established with the NasDem Party elite. The involvement of NasDem Party elite figures in the approach to celebrity legislative candidates is quite a powerful influence. Thus, af- 


\section{Jurnal Ilmu Sosial Volume 19 | Issue 2| December 2020 | Page 117-136}

ter being recruited, the presence of celebrity legislative candidates still gets the attention of the NasDem Party in addition to political education and social relations.

\section{CONCLUSION}

Celebrities recruited by the NasDem Party in the 2019 Legislative Election were used as ornament to beautify the course of political contestation by using a talent scouting pattern by offering and inviting celebrities to be legislative candidates. The NasDem Party uses a legislative candidate recruitment pattern in the form of (1) Open recruitment, by accepting registration from various groups and being published through various media such as newspapers, television, and social media; (2) Talent scouting, namely by picking up and applying for legislative candidates who are considered capable of carrying out the duties of the NasDem Party; (3) Grooming, namely through a communication network that is already owned and has been well cared for and then recruited to become a legislative candidate; and (4) "character recommendations," namely by asking for recommendations from several figures who are considered to be able to provide name recommendations to be nominated as candidates for the NasDem Party. While the approach to celebrity legislative candidates is made in two ways, namely: (1) Involving the role of party elites to approach celebrities, and (2) involving celebrities to invite fellow celebrities to become NasDem Party, legislative candidates. A friendly and conducive atmosphere is the key to building harmony within the NasDem Party. Factors that encourage celebrities to become a NasDem Party legislative candidate are, first, the support provided by the NasDem Party, both morally (debriefing, coaching, and active interaction with party elites) and materially (Campaign Props, campaign costs, financial reimbursement) during the campaign period. Second, the political slogan brought by the NasDem Party, namely Indonesian Restoration and anti-dowry politics, in accordance with the desired positive conditions. Third, a familiar egalitarian political stance through the party elite's approach towards celebrity legislative candidates.

\section{ACKNOWLEDGEMENT}

Thanks to all those who have helped and provided support in completing this research article. Input and criticism of helpful suggestions are expected in the context of developing further research. 


\section{Jurnal Ilmu Sosial Volume 19 | Issue 2| December 2020 | Page 117-136}

\section{BIBLIOGRAPHY}

Adela, Fernanda Putra. (2012). Proses Rekrutmen Politik Calon Anggota Legislatif Lokal Di Medan pada Pemilu 2009. Perspektif, 5(1): 1-11 (doi: 10.31289/perspektif.v2i1.102), [Online].

Adi Prasojo, Teguh. (2013). Pola Rekrutmen Calon Anggota Legislatif (Caleg) dari Partai Golkar untuk DPRD Jateng Periode 2014-2019. Politika: Jurnal Ilmu Politik, 4(2): 21-29 (doi: 10.14710/politika.4.2.2013.21-29), [Online].

Aditya, Willy. (2012). Mari Bung Rebut Kembali. Jakarta: PT Gramedia 2012.

Aditya, Willy (2019). Interview results conducted on June 24, 2019 (Office of the Central Board of the NasDem Party).

Afdhal. (2019). Interview results conducted on March 31, 2019 (Central Java Electoral District IV).

Ananda, Putra. (2018). Target 100 Kursi Nasdem Semakin Realistis. MEDIA Indonesia [online]. Retreieved from https://mediaindonesia.com/read/detail/199657-target-100-kursi-nasdemsemakin-realistis.html (Accessed August 17, 2019).

Andriyani, Livy. (2019). Interview results conducted on March 31, 2019 (Kantor DPW Partai NasDem Jawa Tengah).

Antolin, Bertrand. (2019). Interview results conducted on March, 312019 (Office of the Regional Council Board of the Nasdem Party, Central Java).

Asmara, Chandra Gian. (2019). Gaji, Tunjangan, \& Pensiunan Anggota DPR yang Menggiurkan. CNBCIndonesia [online]. Retrieved from https://www.cnbcindonesia.com/ news/20190411094406-4-65923/gaji-tunjangan-pensiunan-anggota-dpr-yangmenggiurkan (Accessed August 20, 2019).

Asshidiqie, Jimly. (2008). Pokok-Pokok Hukum Tata Negara Indonesia Pasca Reformasi. Jakarta: Bhuana Ilmu Populer.

Astuti, Nur Azizah R. (2019). 31 Caleg Petahana Pilih Pindah Partai Nasdem Jadi Tujuan Favorit. DetikNews [online]. Retrieved from https://news.detik.com/berita/d-4385673/31caleg-petahana-pilih-pindah-partai-nasdem-jadi-tujuan-favorit (Accessed August 6, 2019).

Bjarnegård, E., \& Kenny, M. (2015). Revealing the "Secret Garden": The Informal Dimensions of Political Recruitment. Politics \& Gender, 11(4): 748-753 (doi: 10.1017/ S1743923X15000471), [Online] 


\section{Jurnal Ilmu Sosial Volume 19 | Issue 2| December 2020 | Page 117-136}

Budiardjo, Miriam. (2008). Dasar-Dasar Ilmu Politik. Jakarta: PT Gramedia Pustaka Utama.

Budiartie, Gustidha. (2019). Bukan Mimpi, Tukang Mebel Mebel Sampai Pelawak Bisa Jadi Presiden!. CNBCIndonesia [online]. Retrieved from https://www.cnbcindonesia.com/ news/20190402124715-4-64297/bukan-mimpi-tukang-mebel-sampai-pelawak-bisa-jadipresiden (Accessed April 28, 2019).

Bungin, Burhan et al. (2012). Metodologi Penelitian Kualitatif. Jakarta: Rajagrafindo Persada.

Creswell, John W. (2016). Research Design Pendekatan Metode Kualitatif, Kuantitatif, Dan Campuran. Yogyakarta: Pustaka Pelajar.

Darmawan, Ikhsan. (2015). Keterlibatan Selebriti dalam Pemilu Indonesia Pasca Orde Baru. Sosiohumaniora, 18(3): 236-242 (doi: 10.24198/sosiohumaniora.v17i3.8341), [Online]

Deannova, Alfito. (2008). Selebritis Mendadak Politisi. Yogyakarta: Arti Bumi Intaran.

DetikNEWS. 2009. 18 Artis Masuk Senayan, Demokrat Paling Banyak. [Online]. Retrieved from https://news.detik.com/pemilu/d-1137981/18-artis-masuk-senayan-demokrat-palingbanyak (Accessed April 28, 2019).

Driessens, Olivier. (2013). Celebrity Capital: Redefining Celebrity Using Field Theory. Theory and Society, 42 (5): 543-560 (doi: 10.1007/s11186-013-9202-3), [Online]

Fairuz, Ahmad Adly. (2019). Interview results conducted on March 31, 2019 (Office of the Regional Council Board of the Nasdem Party, Central Java).

Febrian, Andreas Ricky. (2019). CSIS Rilis Survey Migrasi Caleg, Nasdem Jadi Tujuan Favorit. KumparanNEWS [online]. Retrieved from https://kumparan.com/kumparannews/csis-rilis -survei-migrasi-caleg-nasdem-jadi-tujuan-favorit-1547532866204016066

(Accessed August 17, 2019).

Fitriyah. (2018). Politik Dinasti pada Kandidasi Perempuan dalam Pilkada Serentak 2015 di Jawa Tengah. Jurnal Ilmu Sosial, 17(1): 39-52 (doi: 10.14710/jis.17.1.2018.39-52), [Online].

Gerintya, Scholastica. (2018). Hanya 16 Persen Caleg Artis yang Lolos Pemilu 2014. Tirto.id [online]. Retrieved from https://tirto.id/hanya-16-persen-caleg-artis-yang-lolos-pemilu2014-cPVe (Accessed April 28, 2019).

Haboddin, Muhtar. (2016). Pemilu dan Partai Politik di Indonesia. Malang: UB Press. 


\section{Jurnal Ilmu Sosial Volume 19 | Issue 2| December 2020 | Page 117-136}

Haris, Syamsuddin et al. (2016). Panduan Rekrutmen \& Kaderisasi Partai Politik Ideal di Indonesia. Jakarta: Direktorat Pendidikan dan Pelayanan Masyarakat Pencegahan, Komisi Pemberantasan Korupsi Bekerja sama dengan Pusat penelitian Politik, Lembaga Ilmu Pengetahuan Indonesia (P2Politik LIPI).

Karyawati, Dewi Utami. (2011). "Pola Marketing Politik Caleg Selebriti Dalam Menghadapi Kampanye Pemilu 2009”. Thesis. Universitas Diponegoro, Semarang.

Labolo, Muhadam dan Teguh Ilham. (2015). Partai Politik Dan Sistem Pemilihan Umum Di Indonesia (Teori, Konsep dan Isu Strategis). Jakarta: Rajagrafindo Persada.

Meyer, Thomas. (2012). Peran Partai Politik dalam Sebuah Sistem Demokrasi:Sembilan Tesis. Jakarta: Friedrich-Ebert-Stiftung (FES).

Mochtar, Mas'oed dan Coloin Mac Andrews. (1999). Perbandingan Sistem Politik. Yogyakarta: Gadjah Mada University Press.

Moleong, Lexy J. (2002). Metodologi Penelitian Kualitatif. Bandung: PT REMAJA ROSDAKARYA.

Mukti, Krisna. (2019). Interview results conducted on March, 312019 (The Great Campaign of NasDem Party in Kudus).

Pambudi, Dhawam. (2019). INFOGRAFIK: Daftar 14 Artis yang Jadi Anggota DPR 2019-2024. Kompas.com [online]. Retrieved from https://www.kompas.com/tren/ $\mathrm{read} / 2019 / 09 / 23 / 092449065 /$ infografik-daftar-14-artis-yang-jadi-anggota-dpr-2019-2024 (Accessed April 28, 2019).

Preece, Jessica Robinson \& Stoddard, Olga \& Fisher, Rachel. (2015). Run, Jane, Run! Gendered Responses to Political Party Recruitment. Political Behavior, 38: $561-577$ (doi: 10.1007/ s11109-015-9327-3), [Online]

Riyadh, Ahmad \& Sukmana, Hendra. (2015). Model Rekrutmen Politik Calon Anggota Legislatif Oleh Partai Politik Di Kabupaten Sidoarjo. JKMP, 3(2): 179-198 (doi: 10.21070/ jkmp.v3i2.191), [Online]

Sandra, Luky et al. (2017). Partai Dan Sistem Kepartaian Era Reformasi. Yogyakarta: Pustaka Pelajar.

Saputro, Iman Dwi. (2019). Interview results conducted on March 31, 2019 (The Great Campaign of NasDem Party in Kudus).

Šimunjak, Maja \& Street, John (2016). Media portrayals: from leadership cults to celebrity politicians. In: The Routledge Companion to Leadership. Routledge Companions in Business, Management and Accounting, Routledge, Oxon, pp. 450-464. (doi: 9781138825574), [Online] 


\section{Jurnal Ilmu Sosial Volume 19 | Issue 2| December 2020 | Page 117-136}

Soekanto, Soerjono dan Sri Mamudji. (2011). Penelitian Hukum Normatif (Suatu Tinjauan Singkat). Jakarta: RajaGrafindo Persada.

Tantri, Dyah Putri Efrina dan Muradi. (2017). Popularitas Selebriti sebagai Alat Kosmetika Politik. CosmoGov, 3(1): 103-115 (doi: 10.24198/cosmogov.v3i1.12640), [Online].

Thakur, Sandeep Kumar \& Patra, Sidheswar. (2017). Celebrity Advertising and Its Role to Brand Equity: A Review. Asian Journal of Management, 8(3), 925-929. (doi: 10.5958/23215763.2017.00142.1), [Online] 